Indonesia Journal of Learning Education and Counseling

Website: https://journal.ilininstitute.com/index.php/IJoLEC

Vol 2, No 1, 2019, pp 01-08

p-ISSN:2622-8068 dan e-ISSN: 2622-8076

\title{
Model Pembelajaran Radec (Read-Answer-Discuss-Explain And Create): Pentingnya Membangun Keterampilan Berpikir Kritis Dalam Konteks Keindonesiaan
}

\author{
Yoga Adi Pratama ${ }^{1}$, Wahyu Sopandi ${ }^{1}$, Yayuk Hidayah ${ }^{2}$ \\ ${ }^{1,1}$ Program Studi Pendidikan Dasar, Universitas Pendidikan Indonesia \\ Email: yoga.a@student.upi.edu \\ ${ }^{2}$ Pendidikan Guru Sekolah Dasar, Universitas Ahmad Dahlan Yogyakarta \\ Email: wahyusopandi@gmail.com
}

\begin{abstract}
Artikel info
Artikel history:

Received; Januari-2019

Revised:Mei-2019

Accepted:Juni-2018

Publish: Agustus-2019
\end{abstract}

DOI:

doi.org/10.31960/

ijolec.v2i1.99
Abstract. The purpose of writing this article is to describe the RADEC learning model in building critical thinking skills. This study is in the background by the need for a learning model that fits the Indonesian context to build critical thinking skills that can be used at the elementary school level. This study uses the literature review. This study produces one solution to be able to build critical thinking skills is to use the RADEC learning model (read-answerdiscuss-explain and create). The approach in learning that is done by the teacher plays a role in fostering critical thinking skills. The teacher needs to use a learning model that can stimulate students' critical thinking skills.

Abstrak. Tujuan dari penulisan artikel ini adalah untuk mendeskripsikan model pembelajaran RADEC dalam membangun keterampilan berpikir kritis. Kajian ini di latar belakangi oleh perlunya ada model pembelajaran yang sesuai dengn konteks Indonesia untuk membangun keterampilan berpikir kritis yang dapat digunakan di tingkat sekolah dasar. Kajian ini menggunakan literature review. Kajian ini menghasilkan salah satu solusi untuk dapat membangun keterampilan berpikir kritis adalah dengan menggunakan model pembelajaran RADEC (read-answer-discuss-explain and create). Pendekatan dalam pembelajaran yang di lakukan oleh guru berperan dalam menumbuhkan keterampilan berpikir kritis. Guru perlu menggunakan model pembelajaran yang dapat merangsang kemampuan berfiikir kritis siswa.

\section{Keywords:}

Model

Pembelajaran

RADEC;

Berpikir Kritis;
Coresponden author:

Cicalengka, Bandung

Emailyoga.a@student.upi.edu

artikel dengan akses terbuka dibawah licenci CC BY-NC-4.0 


\section{2 | Indonesia Journal of Learning Education and Counseling}

\section{PENDAHULUAN}

Abad 21 adalah abad digital yang ditandai oleh perkembangan teknologi informasi dan komunikasi yang sangat pesat. Perkembangan teknologi informasi tersebut memberikan perubahan pada seluruh aspek konstelasi kehidupan. Implikasinya setiap bangsa termasuk Indonesia harus menyesuaikan dengan tuntutan zaman tersebut. Menurut Binkley, et al. (2012, hlm. 18-19) untuk mampu hidup di abad 21, diperlukan sepuluh keterampilan yang harus dimiliki siswa, keterampilan tersebut antara lain keterampilan berpikir kreatif, berpikir kritis, berpikir metakognisi, komunikasi, kolaborasi, literasi informasi, literasi TIK (Teknologi Informasi Komunikasi), berkewarganegaraan, bekerja dan berkarir, serta keterampilan responsibilatas individu dan sosial. Lebih lanjut Trilling \& Fadel (2009, hlm. 47) menggagas konsep pelangi keterampilan dan pengetahuan yang harus dimiliki di abad 21. Keterampilan tersebut meliputi ketarampilan belajar dan berinovasi yang didalamnya terdapat kemampuan berpikir kreatif dan kemampuan memecahkan masalah, kemampuan komunikasi dan kolaborasi, dan kemampuan untuk berkreativitas dan berinovasi. Keterampilanketerampilan tersebut merupakan dasar esensial untuk seseorang agar mampu bereksistensi di abad 21.

Dengan menggunakan pendekatan holistik, Center for Curriculu mendesain kurikulum dengan menawarkan empat dimensi pendidikan: pengetahuan, keterampilan, karakter, dan metakognisi sebagai berikut:

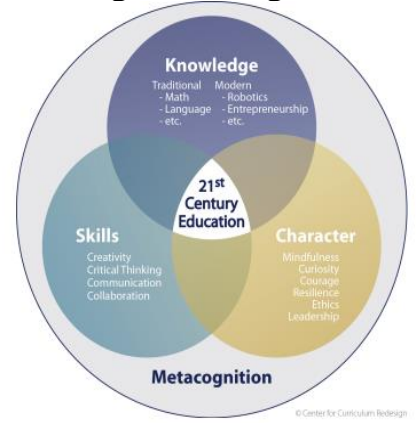

Dengan demikian maka, Salah satu keterampilan yang penting di abad 21 adalah keterampilan berpikir kritis. Kemampuan berpikir kritis perlu dikembangkan dan dibiasakan oleh setiap individu (F. Fakhriyah,
2014). Komponen berfikir kritis termasuk keterampilan meganalisis, menyimpulkan berfikir deduktif, mengevaluasi dan penyelesaian masalah (Emily R. Lai, 2011). Sementara itu, The National Council for Excellence mendefinisikan berfikir kritis adalah konseptualisasi penerapan menganalisis, mensistesis, mengevaluasi mengevaluasi informasi yang di dapat melalui pengalaman, penerapan dan refleksi (Maya Bialik, Charles Fadel, 2015)

Kemampuan berfikir kritis perlu di miliki setiap individu guna mencapai keseimbangan di abad 21, terutama adalah guru Sekolah Dasar. hal ini di karenakan para guru abad ke-21 membutuhkan penguasaan konten keterampilan mengajar serta mengintegrasikan pengajaran dengan teknologi (Hafsah Jan, 2017) di abad 21 antara nasional dan internasional akan saling bersinggungan (Helen B. Boholano, 2017). Namun demikian, dalam praktik pembelajaran guru cenderung kurang peduli untuk meningkatkan kemampuan berpikir kritis. Kurangnya kepedulian tersebut tercermin dari hasil studi PISA dan TIMSS. Meskipun mengalami peningkatan, yakni peringkat ke 64 dari 65 negara pada tahun 2012 (OECD, 2013) dan peringkat 64 dari 72 negara pada tahun 2015 (OECD, 2017) tetap saja Indonesia masih berada pada tataran rendah. Indonesia masih ada pada tataran low ability jika dilihat dari aspek kognitif (knowing, applying, reasoning) (Kusuma, dkk., 2017). Senada dengan PISA, hasil studi TIMSS siswa Indonesia pada tahun 2011 menempati peringkat 40 dari 42 negara dan pada tahun 2015 menempati peringkat 45 dari 48 negara (TIMSS, dalam Nugroho, 2018). Hasil-hasil studi tersebut cukup membuktikan bahwa siswa Indonesia lemah dalam kemampuan berpikir kritis.

Penyebab utama dari rendahnya kemampuan berpikir kritis adalah karena pembelajaran masih mengadopsi pembelajaran tradisional, yakni berpusat pada guru. Dominasi guru pada saat pembelajaran terlalu tinggi sehingga membuat siswa menjadi hanya menjadi obyek pembelajaran semata. Berdasarkan penelitian yang dilakukan oleh Saido, dkk. (2015) menyimpulkan bahwa guru cenderung membelajarkan siswa untuk menghafal, sementara pembelajaran inovatif yang 
bersifat penyelidikan masih kurang dilaksanakan oleh guru. Hasil tersebut sejalan dengan penelitian Sopandi, dkk. (2018) yang menyatakan guru tidak memahami sintaks model pembelajaran inovatif, maka dampaknya model pembelajaran konvensional tetap menjadi andalan para guru. Aktivitas di kelas didominasi oleh sistem penugasan dan hafalan memperlihatkan bahwa rendahnya keterlibatan kemampuan berpikir siswa di dalam pembelajaran (Tembang, 2017). Masih banyak materi-materi hafalan yang terdapat pada short term memory, sehingga kemampuan berpikir siswa di Indonesia hanya pada tataran mengingat, menyatakan kembali, atau merujuk tanpa melakukan pengolahan (recite) (Nugroho, 2018, hlm. 12).

Kurangnya praktik model pembelajaran inovatif ini sangat kurang digunakan guru dalam pembelajaran. Hasil penelitian Sopandi, dkk. (2018) menyebutkan bahwa hanya $10 \%$ guru pendidikan dasar dan menengah seJawa Barat yang bisa menuliskan sintaks dari model pembelajaran inovatif yang paling sering digunakan, sisanya guru tidak memahami dan tidak bisa menuliskan kembali sintaksnya atau bisa dikatakan guru merasa melaksanakan model pembelajaran inovatif, padahal faktanya tidak. Fakta ini memberikan bukti bahwa guru hanya merasa melaksanakan model pembelajaran inovatif. Sehingga bisa kita ketahui bahwa model pembelajaran inovatif masih kurang maksimal diterapkan di Indonesia.

Di sisi lain, salah komptensi dalam kurikulum 2013 adalah mengembangkan kreativitas, rasa ingin tahu, kemampuan merumuskan pertanyaan untuk membentuk pikiran kritis yang perlu untuk hidup cerdas dan belajar sepanjang hayat (Permendikbud, 2013) dengan demikian maka, sudah selayaknya penggunaan model pembelajaran untuk menumbuhkan berfikir ktitis di terapkan dalam proses belajar mengajar oleh guru. Terdapat posisi strategis guru dalam menumbuhkan kemampuan berfikir siswa, pendekatan yang digunakan oleh guru untuk menumbuhkan pemikiran kritis pada siswa (Ni Putu Ayu Nopta Apsari, 2016 ).

Penelitian terdahulu mengenai penggunaan model pembelajaran dalam menumbuhkan berfikir kritis antara lain dilakukan oleh Alifa Noora Rahma (2012)
Pengembangan Perangkat Pembelajaran Model Inkuiri Berpendekatan Sets Materi Kelarutan Dan Hasil kali Kelarutan Untuk Menumbuhkan Keterampilan Berpikir Kritis Dan Empati Siswa Terhadap Lingkungan menghasilkan, proses pembelajaran kimia dengan model inkuiri berpendekatan SETS untuk menumbuhkan kemampuan berpikir kritis ditandai dengan peningkatan skor ratarata pre test dan post test di tiap indikator berpikir kritis yaitu 29,45 menjadi 77,08 . Skor rata-rata indikator kemampuan berpikir kritis pada kegiatan diskusi praktikum sebesar 81,10 . Peningkatan nilai pre-post test $\mathrm{N}$-gain sebesar 0,72 dengan kriteria tinggi. Tercapainya KKM prestasi belajar siswa secara klasikal 83\% dan individual lebih dari atau sama dengan 76 . Skor rata-rata empati siswa terhadap lingkungan selama kegiatan praktikum 82,08. Ali Syahbana (2012) Peningkatan Kemampuan Berpikir Kritis Matematis Siswa Smp Melalui Pendekatan Contextual Teaching And Learning menghasilkan bahwa (1) terdapat perbedaan signifikan dalam peningkatan kemampuan berpikir kritis matematis siswa antara yang pembelajarannya menggunakan Pendekatan Contextual Teaching and Learning dan menggunakan Pendekatan Konvensional, (2) terdapat perbedaan signifikan dalam peningkatan kemampuan berpikir kritis matematis antara siswa pada level pengetahuan awal matematika tinggi, sedang, dan rendah, dan (3) tidak terdapat interaksi antara pendekatan pembelajaran dan level pengetahuan awal matematika siswa terhadap peningkatan kemampuan berpikir kritis matematis siswa. Svetlana Stefanova, Jelena Bobkina, rancisco Javier Sánchez-Verdejo Pérez (2017) The Effectiveness of Teaching Critical Thinking Skills through Literature in EFL Context: A Case Study in Spain yang meneliti mengenai penggunaan lierasi EFL Context untuk meningkatkan kemampuan berfikir kritis pada siswa. Penelitian ini menghasilkan bahwa penggunaan model ini efektif, khususnya, dalam hal refleksi diri. Selain itu, kegiatan membahas teks-teks sastra dan mengaitkannya dengan masalah saat ini telah terbukti sangat bermanfaat bagi siswa, yaitu memberikan mereka perspektif yang lebih luas yang membantu mereka menafsirkan masalah dunia nyata dengan benar.

Dalam konteks ke Indonesiaan, kita tidak bisa menafikan bahwa model pembelajaran 


\section{4 | Indonesia Journal of Learning Education and Counseling}

yang kebanyak diadopsi dari barat tidak cocok diterapkan di Indonesia. Bukan saja karena siswanya berbeda (tingkat literasi, lingkungan, dan lain-lain), model pemeblajaran inovatif seringkali membutuhkan waktu yang lama. Padahal di Indonesia berlaku kurikulum yang pada dan waktu yang singkat. Sehingga diperlukan model pembelajaran yang sesuai dengan konteks keindonesiaan. Dalam artikel ini peneliti mempunyai setidaknya terdapat dua alasan mengapa kajian ini perlu di lakukan, pertama peneliti berusaha membeirikan solusi alternatif untuk mengembangkan keterampilan berpikir kritis siswa Indonesia, yakni melalui model pembelajaran ReadAnswer-Discuss-Explain and Create (RADEC). Kedua, perlu galakannya kajian-kajian yang solutif untuk menyelesaikan persoalan yang ada di dunia Pendidikan, salah satunya adalah kajian mengenai bagaimana menumbuhkan kemampuan erfikir kritis.

Model pembelajaran RADEC adalah salah satu alternatif model pembelajaran yang sesuai dengan kondisi Indonesia (Sopandi, 2017). Model ini pertama kali diperkenalkan Sopandi (2017) dalam suatu konferensi Internasional di Kuala Lumpur, Malaysia. Nama model ini disesuaikan dengan sintaks yaitu Read, Answer, Discussion, Explain, dan Create (RADEC). Sintaks model RADEC mudah dihafal oleh guru pendidikan dasar dan menengah (Sopandi, dkk. 2018), sehingga tepat digunakan untuk alternatif model pembelajaran inovatif di Indonesia. Selain mudah dihafal sintaksnya, model ini hadir atas dasar sistem pendidikan Indonesia yang menuntut siswa untuk memahami banyak konsep ilmu dalam waktu yang terbatas. Model ini menjadi terobosan terbaru dalam pendidikan yang menginginkan ketercapaian kompetensi abad 21, karakter, dan literasi yang disertai dengan penyiapan pada ujianujian yang diselenggarakan sekolah atau universitas. Beberapa penelitian pun telah membuktikan bahwa model pembelajaran RADEC memiliki dampak positif terhadap hasil belajar, baik yang berorientasi materi yaitu pemahaman konsep (Lukmannudin, 2018), maupun yang berorientasi learning skills yaitu kemampuan berpikir kreatif (Jumanto, dkk. 2018). Sehingga sangatlah bijak jika dalam artikel ini peneliti membahas model pembelajaran RADEC terhadap kemampuan berpikir kritis. Maka judul artikel ini adalah
"Model Pembelajaran Radec (Read-AnswerDiscuss-Explain And Create): Membangun Keterampilan Berpikir Kritis Dalam Konteks Keindonesiaan".

\section{METODE}

Metode yang di gunakan dalam artikel ini adalah studi literature (literature review). Yaitu mengidentifikasi, menganalisis, dan mengsintesis penelitian yang relevan untuk pertanyaan atau topik penelitian tertentu (Kitchenham, 2004) mengutip dari Webster \& Watson dan Kitchenham, Varvana Myllärniemi mengidentifikasi setidaknya ada 3 alasan mengapa literature review di lakukan, yaitu memahami topik yang sudah ada tetapi terfragmentasi, Memahami topik penelitian baru, Mempelajari bagaimana teori atau metode didukung oleh empiris bukti (Varvana Myllärniemi, 2015) sumber yang di gunakan dalam literature review berupa jurnal nasional dan internasional, laporan hasil penelitian, buku, e-book, dan sumber dokumen lainnya yang relevan dengan tema yang di angkat.

\section{HASIL DAN PEMBAHASAN}

Dalam hasil dan pembahasan ini, peneliti secara lengsung temuan penelitian dan membahasnya sehingga dihasilkan kesimpulan.

\section{Pembelajaran Read-Answer-Discuss- Explain-and Create (RADEC)}

Model ini dikembangkan atas dasar hal-hal berikut. Pertama, Pendidikan Nasional bertujuan untuk mengembangkan potensi peserta didik untuk menjadi manusia yang percaya pada Tuhan, berakhlak mulia, sehat, berilmu, cakap, kreatif, mandiri, dan menjadi warga negara yang demokratis dan bertanggung jawab. Dengan demikian, upaya praktik pendidikan yang dilakukan di sekolahsekolah harus mencakup semua aspek (sikap, pengetahuan dan keterampilan). Kedua, pendidikan dewasa ini menunjukkan fakta bahwa sumber belajar baik dalam bentuk buku dan sumber-sumber lain seperti internet dengan mudah diperoleh peserta didik. Fakta lain juga menunjukkan bahwa sering model yang berasal dari negara-negara lain tidak sesuai dengan kondisi di Indonesia. Ketiga, 
menurut teori Vygotsky konstruktivisme sosial, perkembangan kemampuan kognitif pada anak-anak terjadi karena interaksi dengan lingkungan sosial. Dalam teori ini dikenal istilah seperti, tingkat perkembangan aktual, tingkat perkembangan potensial dan Zone of Proximal Development (ZPD). Kemampuan aktual adalah kemampuan peserta didik untuk menyelesaikan tugas tanpa bantuan orang lain. kemampuan potensial adalah kemampuan peserta didik untuk menyelesaikan tugas dengan bantuan orang lain (guru atau teman sebaya). Sementara ZPD adalah daerah antara kemampuan aktual dan kemampuan potensial. Berdasarkan teori Vygotsky maka pembelajaran harus dilakukan pada tingkatan tersebut (Lui, 2012; Vygotsky, 1962). Keempat, pada kelas satu dan kelas dua SD peserta didik belajar membaca huruf, kata, kalimat, dan paragraf teks. Berikutnya di kelas tiga mereka belajar untuk memperoleh pemahaman dari teks-teks. Dengan sering berlatih membaca peserta didik akan lebih terampil dalam keterampilan membaca pemahaman.

Adapun sintaks dari model pembelajaran Read-Answer-Discuss-Explain-and Create (RADEC), sebagai berikut (Sopandi, 2017):

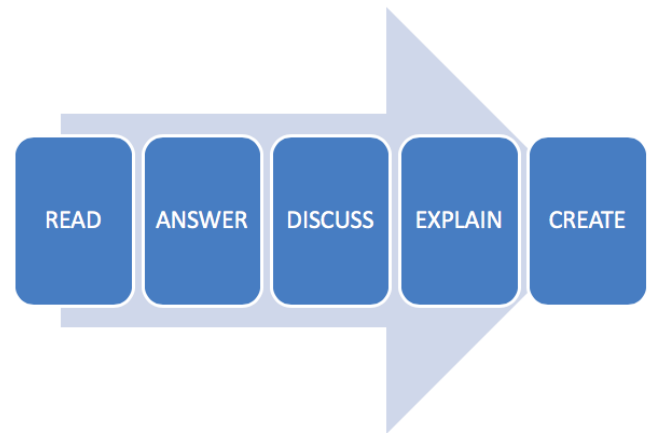

a. $\quad \operatorname{Read}($ Membaca)

Pada tahap ini, peserta didik membaca informasi dari berbagai sumber termasuk buku, sumber informasi lain dicetak dan sumber informasi elektronik seperti internet. Dalam rangka untuk membimbing peserta didik dalam memahami informasi disediakan dengan pertanyaan pra-pembelajaran. Pertanyaan pra-pembelajaran adalah pertanyaan yang berkaitan dengan materi ajar. Pertanyaan-pertanyaan pra-mengajar harus mencakup beragam pertanyaan, dari keterampilan berpikir rendah ke keterampilan berpikir tinggi. Pertanyaan pra-pembelajaran yang diajukan sebelum guru melakukan proses belajar mengajar dari bahan ajar. Peserta didik harus menjawab pertanyaanpertanyaan setelah kegiatan membaca mereka. Kegiatan membaca mereka dilakukan secara mandiri oleh peserta didik di luar kelas. Hal ini didasarkan pada gagasan bahwa beberapa informasi dapat dikuasai oleh peserta didik sendiri tanpa bantuan orang lain. Bahan ajar yang tidak dapat dikuasai oleh peserta didik dapat meminta peserta didik lain untuk menjelaskan atau dijelaskan oleh guru mereka selama sesi kelas. Dengan cara ini sesi kelas dapat lebih fokus baik pada pengembangan aspek-aspek lain (terutama karakter sosial) yang perkembangannya memerlukan interaksi dengan orang lain dan jika bahan ajar yang ditemukan dianggap sulit oleh semua peserta didik.

\section{b. Answer (Menjawab)}

Pada tahap ini peserta didik menjawab pertanyaan-pertanyaan pra-mengajar berdasarkan pengetahuan yang diperoleh kegiatan Read (Membca). Pertanyaanpertanyaan pra-mengajar disusun dalam bentuk worksheet (lembar kerja). Mereka menjawab pertanyaan-pertanyaan di luar kelas atau di rumah secara mandiri sebelum sesi kelas dilakukan. Dengan cara ini adalah mungkin bagi peserta didik untuk mengidentifikasi secara mandiri bagian mana dari bahan ajar dianggap mudah atau sulit. Selain itu, peserta didik sendiri dapat menyadari diri mereka sendiri apakah mereka malas atau rajin membaca, mudah atau sulit untuk memahami bahan ajar tertulis, suka atau tidak suka membaca buku teks, dan lainlain. Selain itu, dengan mengamati tugas peserta didik dan beberapa pertanyaan, guru dapat mengetahui tentang keadaan semua peserta didik. Sangat mungkin bahwa guru akan mengetahui bahwa setiap peserta didik membutuhkan bantuan yang berbeda. Berdasarkan data tersebut, guru dapat memberikan bantuan yang tepat untuk setiap peserta didik.

\section{c. Discuss (Diskusi)}

Pada tahap ini peserta didik belajar dalam kelompok untuk membahas jawaban mereka dari pertanyaan pra-mengajar. Guru 


\section{6 | Indonesia Journal of Learning Education and Counseling}

memotivasi peserta didik berhasil dalam melakukan tugas-tugas tertentu dari LKS untuk memberikan bimbingan kepada temanteman yang belum menguasai mereka. Guru juga memotivasi peserta didik yang belum menguasai untuk meminta bimbingan dari teman mereka. Tahap ini memberikan peserta didik untuk berdiskusi terhadap jawaban mereka dengan anggota lain dalam satu kelompok. Pada tahap ini guru harus memastikan bahwa ada komunikasi antara peserta didik dalam setiap kelompok untuk mendapatkan jawaban yang benar. Dengan melihat aktivitas seluruh kelompok, guru juga dapat menemukan kelompok yang telah menguasai bahan ajar yang dipelajari. Dengan cara ini guru juga dapat mengetahui kelompok atau yang telah memiliki ide-ide kreatif sebagai bentuk penerapan konsepkonsep yang telah dikuasai.

\section{d. Explain (Menjelaskan)}

Pada tahap ini, melakukan kegiatan presentasi. Bahan ajar yang disajikan mencakup semua indikator pembelajaran aspek kognitif yang telah dirumuskan dalam rencana pelajaran. Urutan presentasi disesuaikan dengan urutan indikator pembelajaran dirumuskan dalam rencana pelajaran. Pada tahap ini perwakilan peserta didik ini yang telah menguasai indikator pembelajaran untuk menjelaskan konsepkonsep penting di depan kelas. Dalam kegiatan ini juga, guru memastikan bahwa presenter menjelaskan secara ilmiah benar dan peserta didik lain memahami penjelasannya. Dalam kegiatan ini guru juga mendorong peserta didik lain untuk bertanya, membantah, atau menambah apa yang telah disampaikan oleh temannya dari kelompok lain. Pada tahap ini juga dapat digunakan oleh guru untuk menjelaskan konsep-konsep penting yang tidak bisa dikuasai oleh semua peserta didik seperti yang diamati pada tahap diskusi. Ketika menjelaskan, guru dapat memberikan penjelasan dengan demonstrasi, video, power point atau hal-hal lain yang diharapkan dapat mengatasi kesulitan peserta

\section{SIMPULAN DAN SARAN}

Dari analisis data yang peneliti lakukan, maka peneliti dapat menyimpulkan bahwa salah satu solusi untuk dapat membangun didik.

\section{e. Create (Membuat)}

Pada tahap ini, guru memfasilitasi peserta didik untuk belajar menggunakan pengetahuan mereka yang telah dikuasai untuk menghasilkan ide-ide atau pemikiran kreatif. Berpikir kreatif dapat dirumuskan sebagai pertanyaan produktif, masalah, atau pikiran membuat karya-karya kreatif lainnya. Seperti disebutkan sebelumnya, tugas menciptakan ide-ide atau pemikiran kreatif sudah tercakup dalam pertanyaan-pertanyaan pra-pembelajaran. Jadi pada tahap ini hanya membahas hal itu dengan cara klasik karena peserta didik sebelumnya telah ditugaskan untuk melakukannya secara mandiri. Ketika guru menemukan peserta didik mengalami kesulitan untuk menghasilkan ide-ide kreatif, guru perlu menginspirasi para peserta didik. Sumber inspirasi yang diberikan oleh guru bisa dalam bentuk contoh penelitian, pemecahan masalah atau pekerjaan lain yang telah dilakukan oleh orang-orang. Kemudian peserta didik mendiskusikan ide-ide kreatif lain yang dapat direncanakan dan direalisasikan. Sebagai inspirasi lain bagi peserta didik, guru dapat memberikan contoh rencana kreatif yang tidak pernah direalisasikan baik oleh dirinya sendiri atau orang lain. Dalam keadaan peserta didik tidak memiliki ide-ide mereka sendiri sehingga mereka dapat bekerja pada ide guru. Realisasi ide bias dilakukan secara mandiri atau dalam kelompok tergantung pada karakter yang akan dikembangkan. Pekerjaan ini secara teoritis lebih menantang untuk peserta didik karena ide asli. Selain itu, ide dapat diwujudkan baik berhasil atau tidak berhasil. Selain itu, Realisasi ide bisa di dalam kelas atau di luar kelas, bisa sebentar atau juga bisa panjang. Tahap ini melatih peserta didik dominan untuk berpikir, bekerja sama, berkomunikasi. Mereka belajar untuk menemukan ide-ide kreatif, mengambil ideide yang akan diwujudkan, rencana realisasi, melaksanakan rencana tersebut

keterampilan berpikir kritis dalam konteks keIndonesiaan adalah dengan menggunakan model pembelajaran RADEC (read-answerdiscuss-explain and create). Keterampilan 
berpikir kritis penting untuk di kebangkan karena tuntutan dari permkebangan jaman yang terus berubah. Pendekatan dalam pembelajaran yang di lakukan oleh guru berperan dalam menumbuhkan keterampilan berpikir kritis. Guru perlu menggunakan model pembelajaran yang dapat merangsang kemampuan berfpikir kritis siswa.

\section{DAFTAR RUJUKAN}

Alifa Noora Rahma, (2012). Pengembangan Perangkat Pembelajaran Model Inkuiri Berpendekatan Sets Materi Kelarutan Dan Hasilkali Kelarutan Untuk Menumbuhkan Keterampilan Berpikir Kritis Dan Empati Siswa Terhadap Lingkungan. Journal of Educational Research and Evaluation JERE 1 (2) http://journal.unnes.ac.id/sju/index.ph $\mathrm{p} /$ jere

F. Fakhriyah, (2014). Penerapan Problem Based Learning Dalam Upaya Mengembangkan Kemampuan Berpikir Kritis Mahasiswa. Jurnal Pendidikan IPA Indonesia. JPII 3 (1) (2014) 95-101. http://journal.unnes.ac.id/nju/index.p $\underline{\mathrm{hp} / \mathrm{jpii}}$

Hafsah Jan, (2017). Teacher of 21st Century: Characteristics and Development. ISSN (Paper) 2224-5766 ISSN (Online) 22250484 (Online) Vol.7, No.9, 2017 www.iiste.org

Helen B. Boholano, (2017). Smart Social Networking: 21st Century Teaching And Learning Skills. Research in Pedagogy, Vol. 7, Issue 1 (2017), pp. 21-29 DOI: $10.17810 / 2015.45$

Ni Putu Ayu Nopta Apsari, (20160. Teacher's Way To Foster Critical Thinking In The Classroom (A Case Study of a Senior High School in Bandung). Journal of English and Education , 4(1), 51-72

Sopandi, W. Pratama, Y.A., \& Handayani, H. (2018). Profil Perubahan Kompetensi Pedagogik Guru Pendidikan Dasar Dan Menengah Melalui Sosialisasi Dan Workshop Read-Answer-Discuss-
Explain-And Create (RADEC), Premiere Educandum: Jurnal Pendidikan Dasar dan Pembelajaran, 8 (1).

Saido, G. M., Siraj, S., Nordin, A. B. B., Al Amedy, O. S. (2015). Higher Order Thinking Skills Among Secondary School Students in Science Learning, The Malaysian Online Journal of Educational Science, Volume 3 Issue 3, hlm. 13-20.

Tembang, Y. Sulton, \& Suharjo. (2017). Peningkatan Motivasi Dan Hasil Belajar Melalui Model Pembelajaran Think Pair Share Berbantuan Media Gambar Di Sekolah Dasar. Jurnal Pendidikan Universitas Negeri Malang. 2(6): 812817.

Sopandi, W. (2017). the Quality Improvement of Learning Processes and Achievements Through the ReadAnswer-Discuss-Explain-and. Dalam C. M. Keong, L.L. Hong, \& R. Rao (Penyunting), Proceeding 8th Pedagogy International Seminar 2017, 8, 132-139. Kuala Lumpur: Institut Pendidikan Guru Kampus Ilmu Khas

Jumanto, Sopandi, W., Kuncoro, Y., Handayani, H., \& Suryana, N. (2018). The Effect Of Radec Model And Expositorial Model On Creative Thinking Ability In Elementary School Students In Suralaya. Dalam Syaodih, Sujana, Handayani \& William (Penyunting). Prosiding International Conference on Elementary Education (hlm. 561-567). Bandung: Universitas Pendidikan Indonesia.

Kusuma, M. D., Rosidin, U., Abdurrahman, \& Suyatna, A. (2017). The Development of Higher Order Thinking Skill (Hots) Instrument Assessment In Physics Study, IOSR Journal of Research \& Method in Education (IOSR-JRME), 7 (1), hlm. 26-32, DOI: 10.9790/7388-0701052632

Peraturan Menteri Pendidikan Nasional. 


\section{Indonesia Journal of Learning Education and Counseling}

Permendikbud, Tentang Kurikulum Tahun 2013

Buku:

Emily R. Lai, (2011). Critical Thinking: A Literature Review Research Report. London: PEARSON

Kitchenham, Barbara.(2004). Procedures for performing systematic reviews. Technical report TR/SE0401, Keele University

Maya Bialik, Charles Fadel, (2015). Skills for the 21st Century: What Should Students Learn?. Boston: Center for Curriculum Redesign

Binkley, M., et al. (2012). "Defining TwentyFirst Century Skills" dalam Assessment and Teaching of 21st Century Skills. New York: Springer.

Trilling, B. \& Fadel, C. (2009). 21st Century Skills: Learning for Life in Our Times. San Francisco: Jossey-Bass A Wiley Imprint.

OECD. (2013). PISA 2012 Results: What Students Know and Can Do Student Performance in Mathematics, Reading and Science Volume I.

OECD. (2017). Educational Opportunity for All.

https://doi.org/10.1787/978926428745 $\underline{\text { 7-en }}$

Nugroho, R. A. (2018). HOTS (Kemampuan Berpikir Tingkat Tinggi: Konsep, Pembelajaran, Penilaian, dan Soal-soal). Jakarta: PT Gramedia Widiasarana Indonesia

Lukmanudin. (2018). Penguasaan Konsep IPA dan Kemampuan Menjelasakan Perpindahan Zat Pencemar Mahasiswa PGSD melaui Pembelajaran ReadAnswer-Discuss-Explain-and Create. (Tesis). Jurusan Pendidikan Dasar Sekolah Pascasarjana Universitas Pendidikan Indonesia.

Lui, A. (2012). Teaching in the Zone. An Introduction to Working Within the
Zone of Proximal Development (ZPD) to Drive Effective Early Childhood Instruction.

Vygotsky, L.S. (1962). Thought and Language: Kap. 6 The Development of Scientific Concepts in Childhood, Übersetzt von Eugenia Hanfmann und Gertrude Vakar, New York and London: MIT Press - John Wiley \& Sons, Inc, S.

Presentasi :

Varvana Myllärniemi, (2015). Literature review as a research method. Espoo : Aalto University School of Science 